\title{
INOVASI MANAJEMEN PEMBELAJARAN DALAM MENINGKATKAN KUALITAS PENDIDIKAN ISLAM BAGI SISWA DI MAN BATUBARA
}

\author{
Makmur Syukri \\ Universitas Islam Negeri Sumatera Utara Medan \\ *Korespodensi: makmursyukri@uinsu.ac.id
}

\begin{abstract}
ABSTRACK
Islamic education is a primary need for students. The problem of moral degradation and crime can be overcome rootedly through quality Islamic education for students. For this reason, learning management innovation is needed to improve the quality of Islamic education for students. This paper aims to analyze learning management innovations in improving the quality of Islamic education for students at MAN Batubara. The formulation of the discussion focused on the analysis of innovation planning, implementation, monitoring and evaluation of learning in improving the quality of Islamic education for students at MAN Batubara. This research was carried out empirically using a qualitative approach, case study method. Data collection was carried out online and offline according to the process, using interview techniques, participant observation and documentation studies. Through this research, the results obtained are that (1) learning planning innovation refers to the results of consultations with the leadership and teachers of MAN Batubara which is held every year, with additional material on the love of Allah and the Apostle through worship; (2) learning implementation innovations are carried out inside and outside the classroom, with additional tahfiz programs and congregational Duha prayers; (3) learning supervision innovations are carried out in a structured manner starting from the Head of MAN with the addition of monitoring by the supervisor from the district ministry of religion; (4) learning evaluation innovations are carried out orally and in writing, starting from aspects of reading the Qur'an and worship practices.
\end{abstract}

Keyword: Innovation, Quality of Islamic Education, Learning Management.

\begin{abstract}
ABSTRAK
Pendidikan Islam merupakan kebutuhan primer bagi siswa. Permasalahan degradasi moral dan tindak kejahatan dapat diatasi secara mengakar melalui pendidikan Islam yang berkualitas bagi siswa. Untuk itu, dibutuhkan inovasi manajemen pembelajaran guna meningkatkan kualitas pendidikan Islam bagi siswa. Tulisan ini bertujuan untuk menganalisa inovasi manajemen pembelajaran dalam peningkatan kualitas pendidikan Islam bagi siswa di MAN Batubara. Formulasi pembahasan difokuskan terkait analisa inovasi perencanaan, pelaksanaan, pengawasan dan evaluasi pembelajaran dalam peningkatan kualitas pendidikan Islam bagi siswa di MAN Batubara. Penelitian ini dilaksanakan secara empirik dengan menggunakan pendekatan kualitatif, metode studi kasus. Pengumpulan data dilakukan secara daring dan luring sesuai prokes, dengan teknik wawancara, observasi partisipan dan studi dokumentasi. Melalui penelitian ini, diperoleh hasil bahwa (1) inovasi perencanaan pembelajaran mengacu pada hasil musyawarah bersama pihak pimpinan dan guru MAN Batubara yang diselenggarakan setiap tahun, dengan tambahan materi cinta Allah dan Rasul melalui ibadah; (2) inovasi pelaksanaan pembelajaran dilakukan di dalam dan di luar kelas, dengan tambahan program tahfiz dan salat Duha berjamaah; (3) inovasi pengawasan pembelajaran dilakukan secara terstruktur mulai dari Kepala MAN dengan ditambahkan monitoring pihak pengawas dari kemenag kabupaten; (4) inovasi evaluasi pembelajaran dilakukan secara lisan dan tertulis, mulai dari aspek membaca alQur'an dan praktik ibadah.
\end{abstract}

Kata Kunci: Inovasi, Kualitas Pendidikan Islam, Manajemen Pembelajaran. 


\section{A. PENDAHULUAN}

Siswa atau peserta didik merupakan "aset kehidupan” yang berhak memperoleh bekal berupa pendidikan (Fitri, et.al., 2015; Sujatmoko, 2010; Fitriani, 2016; Sudrajat, 2011), termasuk pendidikan Islam (Siregar, 2016). Kebutuhan siswa pada setiap jenjang formal pendidikan terhadap pendidikan Islam yang berkualitas terbilang primer (Sada, 2017), sebab menjadi landasan dasar aspek sosial, emosional, budaya, dan pergaulan siswa pada fase kehidupannya (Djaelani, 2013). Dalam konteks ini, orangtua di lingkungan keluarga dan guru di lingkungan madrasah/sekolah, bertanggungjawab penuh mem-fasilitasi pendidikan Islam bagi siswa (Taubah, 2015; Usman, 2017).

Tanggung jawab orangtua dalam mem-fasilitasi pendidikan anak (siswa), tidak sekadar mengajari anak di rumah. Sebab, anak juga butuh berinteraksi secara sosial dengan teman sebaya dan orang lain (Nurmalitasari, 2015; Assingkily \& Mikyal, 2019). Untuk itu, upaya pemenuhan tanggung jawab orangtua diimbangi dengan menyekolahkan anak di lembaga pendidikan, mulai jenjang pendidikan anak usia dini (PAUD), RA/TK, pendidikan dasar, pendidikan menengah hingga jenjang pendidikan tinggi (Sholikhah, et.al., 2019; Pamela, et.al., 2015; Putriani, 2015; Vitasari, 2017).

Bila diurai, maka usia setiap individu berupaya menemukan jati diri terdapat pada fase usia remaja (Trenggonowati \& Kulsum, 2018). Pada fase ini, orangtua berkewajiban memberikan fasilitas pendidikan Islam yang berkualitas bagi kehidupan anak di masa mendatang (Notosrijoedono, 2016). Melalui pendidikan Islam, usia remaja akan lebih survive menghadapi gejolak dan permasalahan kehidupan yang ditemuinya kelak di masa dewasa.

Atas dasar kebutuhan, tuntutan dan tanggungjawab tersebut, meniscayakan pihak lembaga pendidikan untuk melakukan inovasi manajemen pembelajaran yang sesuai dengan fase perkembangan remaja (Munawaroh, 2017; Ita, 2018; Aryani \& Fitriani, 2020). Adapun orientasinya difokuskan terutama pada aspek perkembangan moral dan agama (Khaironi, 2017; Hasanah, 2018; Inawati, 2017). Melalui inovasi manajemen pembelajaran yang berorientasi moral dan agama, maka anak dapat mengenal, memahami, dan mencintai Islam sebagai agamanya, serta terpatri sikap toleransi dan menghargai perbedaan yang ada di sekitarnya (Noor, 2020).

Berdasarkan studi pendahuluan di MAN Batubara, diperoleh informasi 
bahwa lembaga tersebut berupaya menyahuti kebutuhan siswa (fase usia remaja) akan pendidikan Islam yang mumpuni dan berkualitas, mulai dari penyajian program pembelajaran, kegiatan Islami ditambah dengan pakaian yang mem-budayakan karakteristik Islami pada remaja (siswa).

Sejatinya, penelitian tentang inovasi manajemen pembelajaran telah banyak diteliti sebelumnya. Di antaranya membahas tentang inovasi manajemen pembelajaran dari aspek kurikulum 2013 (Nurdyansyah \& Fahyuni, 2016), pembelajaran daring online (Agustin, et.al., 2020; Abadi, 2015), kreatifitas guru (Supriadi, 2017), inovasi melalui model hypnoteaching (Mardhiah, et.al., 2020), profesionalisme guru (Kristiawan \& Rahmat, 2018), pembelajaran era revolusi 4.0 (Widyanto, et.al., 2020), pembelajaran sejarah (Lilian, et.al., 2014), dan pengembangan pembelajaran (Saputro, 2016).

Mencermati literature review tersebut, dibutuhkan penelitian lebih lanjut tentang inovasi manajemen pembelajaran yang berorientasi pada perwujudan pendidikan Islam yang berkualitas, khususnya bagi siswa usia remaja. Penelitian yang dimaksud, terangkum dalam judul "Inovasi Manajemen Pembelajaran dalam Meningkatkan Kualitas Pendidikan Islam Bagi Siswa di
MAN Batubara". Melalui penelitian ini, diharapkan dapat ditemukan konsep prototipe lembaga pendidikan Islam dalam mengimplementasikan inovasi manajemen pembelajaran berorientasi pada kualitas pendidikan Islam bagi siswa (khususnya usia remaja).

\section{B. METODE}

Penelitian ini dilakukan secara empirik melalui pendekatan kualitatif dengan metode studi kasus sebagai "alat atau cara" mengeksplorasi hal baru yang berkaitan dengan objek penelitian (Yin, 2009). Adapun fokus pembahasan penelitian ini yaitu menganalisa inovasi manajemen pembelajaran dalam meningkatkan kualitas pendidikan Islam bagi siswa dengan latar penelitian di MAN Batubara. Penelitian ini dilakukan sejak Januari-April 2021, dengan informan utama yaitu, guru dan siswa MAN Batubara. Selanjutnya informan pendukung yaitu Kepala MAN Batubara.

Pengumpulan data penelitian diperoleh dengan teknik observasi, wawancara, dan studi dokumentasi. Penggunaan teknik tersebut secara luring (menggunakan masker, mencuci tangan dengan sabun) dan daring (via WhatsApp) tetap mematuhi prokes yang berlaku. Selanjutnya, data tersebut dianalisa melalui teknik (1) reduksi data sebagai 
proses pemilahan data, (2) penyajian data secara naratif, dan (3) menarik simpulan.

Terakhir, validitas data penelitian diuji dan penjaminannya melalui teknik triangulasi. Triangulasi yang dimaksud sebagai bentuk penjaringan data, yang selanjutnya dikomparasikan antara data yang satu dengan data lainnya (wawancara informan yang satu, dengan informan lainnya) (Creswell, 2009). Dalam konteks ini, 2 (dua) aspek triangulasi yang dibandingkan, yaitu metode dan sumber data. Dengan demikian, data yang disajikan dan telah memperoleh simpulan valid dan sesuai dengan konteks penelitian.

\section{HASIL PEMBAHASAN}

Pembelajaran adalah hal urgen dalam proses pendidikan (Rahman, 2018; Rosyad, 2019). Sebab, di dalamnya terdapat berbagai komponen yang terintegrasi sebagai suatu sistem (Pane \& Dasopang, 2017; Dolong, 2016). Pembelajaran yang baik dan efektif adalah pembelajaran yang sesuai dengan kebutuhan masyarakat global (Oviyanti, 2013; Dacholfany, 2015). Hal ini meniscayakan pentingnya kreasi dan inovasi dalam pendidikan.

Inovasi pembelajaran dapat dikelola secara efektif dan efisien dengan memperhatikan empat aspek yaitu perencanaan, pelaksanaan, pengawasan dan evaluasi (Khairuddin, 2020). Mengacu pada empat fungsi manajemen tersebut, pembelajaran membutuhkan pembaharuanpembaharuan yang dapat meningkatkan kualitas pendidikan Islam bagi siswa (Maujud, 2018; Almasri, 2016). Lebih lanjut, bentuk inovasi manajemen pembelajaran di MAN Batubara diuraikan pada pembahasan di bawah ini:

\section{Inovasi Perencanaan Pembelajaran di MAN Batubara}

Perencanaan pembelajaran merupakan seperangkat materi tertulis maupun lisan yang disepakati sebagai orientasi pembelajaran dalam satuan lembaga pendidikan (Nadlir, 2013; Nurlaila, 2018). Menurut Prabowo (2010), perencanaan pembelajaran menentukan arah proses pendidikan pada satuan lembaga pendidikan, mulai dari aspek tujuan jangka pendek, menengah maupun jangka panjang.

Lebih lanjut, Prabowo (2010) juga menambahkan bahwa hasil tertulis dari penyusunan perencanaan pembelajaran harus memiliki arah atau orientasi yang jelas, terukur (prediksi) hasilnya, dapat diperkirakan jumlah SDM yang dibutuhkan, dan dapat pula diketahui alternatif pencapaian tujuan pembelajaran. Berkaitan dengan ini, Fitri, et.al. (2017) menginformasikan bahwa penyusunan perencanaan pembelajaran dapat dilakukan secara musyawarah bersama. 
Senada dengan pendapat di atas, Kepala MAN Batubara menuturkan bahwa:

“...Perencanaan pembelajaran di MAN ini biasanya kami susun dan rampungkan sesudah dilakukan musyawarah Pak. Karena kami di MAN ini menerapkan konsep bermusyawarah sebelum mengambil keputusan. Di samping itu, kami juga selalu melibatkan para guru dan tenaga kependidikan, agar keputusan yang diambil membawa kemaslahatan bersama." (Hasil wawancara dengan Erwin Chandra Islamy S, S.Pd.)

Irwansyah Putra, S.Ag., membenarkan pernyataan tersebut, dengan mengatakan bahwa:

“...saya sebagai guru sekaligus wali kelas XI-Agama, mengakui bahwa Pak kepala selalu berunding dengan kami alias musyawarah Pak, dalam mengambil satu kebijakan, termasuk tentang penyusunan perencanaan pembelajaran tiap tahunnya." (Hasil wawancara dengan Guru MAN Batubara).

Mendukung kutipan wawancara di atas, Nurlaeli \& Saryono (2018) menerangkan bahwa musyarawah adalah cara kekeluargaan yang dilakukan oleh satuan lembaga pendidikan dalam mengambil dan menetapkan satu kebijakan. Efektivitas perencanaan pembelajaran melalui proses musyawarah mengindikasikan proses dan tujuan pembelajaran yang jelas dan terukur (Bararah, 2017). Lebih lanjut, Suryapermana (2017) menerangkan bahwa pengelolaan atau manajemen perencanaan pembelajaran harus diimbangi dengan berbagai inovasi dan kebijakan internal satuan pendidikan, sehingga orientasi pembelajaran bersifat baru dan up to date.

Senada dengan pendapat tersebut, Kepala MAN Batubara menambahkan, "...sebagai lembaga pendidikan bercirikan Islam, dengan nama Madrasah Aliyah (Negeri) yang tentu berbeda dengan SMA/SMU/SMK, maka kami juga menambahkan materi keislaman di dalam setiap pembelajaran Pak. Khususnya materi cinta kepada Allah dan Rasul melalui aktivitas ibadah." (Wawancara dengan Pak Erwin Chandra Islamy S, S.Pd.)

Kutipan wawancara di atas, menegaskan peranan lembaga dalam memfasilitasi pendidikan Islam yang berkualitas bagi siswa (usia remaja). Menurut Ulfiyah (2017), melalui pembiasaan dan perilaku mendidik yang diberikan guru akan membantu anak usia dini dalam praktik ibadah. Dalam konteks ini, peran guru sangat dibutuhkan untuk mengembangkan kepribadian dan karakter religius bagi siswa usia remaja, melalui pengalaman dan pengamalan ibadah (Ansori, et.al., 2019; Mafaliha, 2020).

Urgensitas inovasi perencanaan pembelajaran menjadi tolak ukur bagi arah dan tujuan pembelajaran secara berkala di satuan lembaga pendidikan. Hal inilah menjadi dasar penetapan yang dilakukan oleh pihak MAN Batubara dalam 
penyusunan kerangka pembelajaran setiap semester dan tahunannya melalui musyawarah antara pihak pimpinan dan para guru di MAN Batubara, serta penambahan materi cinta Allah dan nabi saw. melalui praktik ibadah. Dengan demikian, penyusunan perencanaan pembelajaran diinovasi dan dikelola dengan baik oleh pihak MAN Batubara sebagai upaya meningkatkan kualitas pendidikan Islam bagi siswa.

\section{Inovasi Pelaksanaan Pembelajaran di MAN Batubara}

Pelaksanaan pembelajaran secara inovatif merupakan tahap implementasi atas perencanaan pembelajaran yang telah disusun sebelumnya. Menurut Rahayu \& Firmansyah (2018) pelaksanaan pembelajaran dapat dilakukan dengan pendampingan yang diberikan guru kepada siswa baik di dalam kelas maupun di luar kelas. Hal senada juga disampaikan oleh Guru MAN Batubara:

\footnotetext{
“...pembelajaran di MAN Batubara kami laksanakan seperti biasa Pak, kadang di dalam kelas, kadang juga di luar kelas. Kalau di dalam kelas, biasanya kami menyampaikan materi yang bersifat teoretis Pak. Sedangkan di luar kelas, kami praktik dan belajar secara kontekstual dengan siswa Pak. Karena, pembelajaran kontekstual lebih tepat bagi siswa usia remaja daripada teori melulu Pak." (Wawancara dengan Nailida Hafni, S.Pd.)
}

Kutipan wawancara di atas, mengkonfirmasi bahwa pembelajaran di MAN Batubara dilaksanakan di dalam dan di luar kelas. Lebih lanjut, Erwin Chandra Islamy S, S.Pd. (Kepala MAN Batubara) menuturkan, “...selain penerapan pembelajaran di dalam dan luar kelas, kami juga menambahkan program tahfiz dan salat Duha berjamaah Pak." Penambahan kegiatan bagi siswa yang diterapkan oleh MAN Batubara merupakan bentuk inovasi pembelajaran pada satuan lembaga. Selanjutnya, ketika peneliti mewawancarai siswa MAN Batubara bernama Riza Al-Ittihad, ia menuturkan: “...iya Pak, saya dan kawan-kawan salat Duha setiap pagi secara berjamaah di masjid, setelah berbaris di lapangan." Siswa lainnya bernama Ernita dan Firma menambahkan, “...sehabis Duha, kami setor hafalan kepada guru tahfiz Pak. Saya (Ernita) udah surah Al-An-Naziat, sedangkan Firma sudah Juz 29."

Menurut Lubis, et.al. (2020), inovasi pelaksanaan pembelajaran dengan tambahan program unggulan di sekolah/madrasah merupakan alternatif dalam mendukung perkembangan bagi siswa. Dalam konteks penambahan kegiatan (program) tahfiz dan Duha berjamaah di MAN Batubara, merupakan bentuk pendukung perkembangan moral dan agama bagi siswa. Dengan demikian, dipahami bahwa pihak MAN Batubara 
melakukan inovasi pelaksanaan pembelajaran dengan kegiatan tambahan merupakan upaya meningkatkan kualitas pendidikan Islam bagi siswa.

\section{Inovasi Pengawasan Pembelajaran di MAN Batubara}

Pengawasan adalah aspek penting dalam menjalankan fungsi manajemen pada pembelajaran (Darussalam, 2020; Asmara \& Nindianti, 2019). Kegiatan pengawasan meliputi pengamatan tertulis dan tidak tertulis dari kinerja guru serta proses pembelajaran, selanjutnya pengawas berwenang memberi saran dan masukan untuk ditindaklanjuti oleh guru, guna mengoptimalkan proses pembelajaran (Tatu, 2019).

Berdasarkan keterangan dari Erwin Chandra Islamy S, S.Pd. (Kepala MAN Batubara), bahwa "...pengawasan pembelajaran dilaksanakan seperti biasa Pak, yaitu dari pihak internal dan eksternal. Pengawas internal meliputi pengawasan Kepala MAN (saya sendiri) ditambah dengan men-delegasikan Wakil Kepala Madrasah (WKM) bidang Kurikulum, sedangkan pengawas eksternal dari kemenag kabupaten". Senada dengan ini, Syafrizal, S.Pd. (WKM Bidang Kurikulum) membenarkan pernyataan tersebut bahwa, “...selama ini saya pribadi memang diminta Pak Kepala untuk ikut mengawasi pembelajaran (akademik) di MAN Pak. Komunikasi dan kolaborasi semacam ini menurut saya tradisi yang baik untuk diterapkan pada satuan lembaga pendidikan."

$$
\text { Menurut Andiyanto (2018), }
$$
pengawasan internal dan eksternal pada satuan pendidikan bertujuan menyeimbangkan hasil pengawasan yang diberikan dan sebagai bentuk minimalisir subjektivitas penilaian, sehingga evaluasi yang diberikan dapat ditindaklanjuti secara optimal oleh guru. Andriana (2015) menambahkan bahwa pengawasan dilakukan sebagai tahap lanjutan dari perencanaan dan pengawasan. Mencermati kolaborasi tindak pengawasan, Nasrin (2021) menyebutnya sebagai upaya peningkatan mutu (kualitas) lembaga pendidikan Islam.

Sejatinya, peningkatan mutu pendidikan Islam adalah tujuan utama dari tindak pengawasan. Seringkali kelalaian administrasi dan akademik terjadi selama proses pembelajaran, untuk itu dibutuhkan pengawasan pembelajaran (Ahmad, 2021). Inovasi pengawasan pembelajaran yang dilakukan oleh pihak pimpinan MAN Batubara yaitu dengan mendelegasikan WKM Bidang Kurikulum dalam upaya pengawasan aspek akademik di MAN Batubara. Dengan demikian, komunikasi dan kolaborasi Kepala Madrasah, WKM Bidang Kurikulum, dan pengawas kemenag kabupaten Batubara dapat 
bersinergi dengan baik dalam meningkatkan kualitas pendidikan Islam bagi siswa.

\section{Inovasi Evaluasi Pembelajaran di}

\section{MAN Batubara}

Evaluasi merupakan tahap akhir dalam siklus proses pembelajaran (Nuriyah, 2016). Tahap perencanaan berikutnya, dimulai dari capaian hasil yang telah dievaluasi, untuk itu tahap ini memiliki peran krusial bagi kemajuan lembaga pendidikan (Fachri, 2018; Rohmah, 2017; Anwar, 2021). Oleh karena itu, penyelenggara pendidikan harus mengevaluasi aspek administrasi dan akademik dengan baik selama proses pembelajaran.

Berkaitan dengan aspek evaluasi, Erwin Chandra Islamy S, S.Pd. menuturkan bahwa:

“...evaluasi di MAN kami lakukan dengan 2 cara Pak, pertama lisan, kedua tertulis. Adapun yang tes tertulis kami mengetes kompetensi siswa tentang al-Qur'an Pak. Kalau yang lisan, kami mengetes tingkat kemahiran siswa dalam membaca al-Qur'an, ditambah juga dengan ujian praktik ibadah Pak." (Wawancara dengan Kepala MAN Batubara)

Kutipan wawancara di atas, menginformasikan bahwa evaluasi yang dilakukan oleh pihak madrasah terdiri dari tes lisan dan tertulis, serta praktik ibadah. Begitupun, Chotimah \& Fathurrohman
(2018) menerangkan bahwa di era globalisasi saat ini, evaluasi pembelajaran yang dilakukan secara tertulis dan lisan tidaklah boleh monoton dari tahun ke tahun tanpa perubahan. Untuk itu, Nurhidayati (2015) menjelaskan bahwa dibutuhkan inovasi evaluasi pembelajaran yang mengedepankan perkembangan bagi siswa.

Adapun bentuk inovasi yang dilakukan oleh pihak MAN Batubara dalam evaluasi pembelajaran yakni berorientasi pada perkembangan moral dan agama pada siswa, meliputi ujian membaca al-Qur'an, uji kompetensi siswa tentang al-Qur'an, ditambahkan dengan praktik ibadah. Dengan demikian, siswa tidak hanya mengikuti ujian secara formalitas, melainkan terbantu perkembangan moral dan agama.

\section{KESIMPULAN}

Berdasarkan hasil penelitian diperoleh simpulan bahwa inovasi manajemen pembelajaran dalam meningkatkan kualitas pendidikan Islam di MAN Batubara terlaksana dengan baik, hal ini ditinjau dari 4 (empat) aspek, yaitu perencanaan (meliputi musyawarah tahunan dan materi keagamaan cinta Allah dan Rasul melalui Ibadah), pelaksanaan (meliputi pembelajaran di kelas dan di luar kelas, program tahfiz dan salat Dhuha berjamaah), pengawasan (meliputi 
pengawasan internal oleh kepala RA dan delegasi kepada WKM bidang Kurikulum, sedangkan pengawasan eksternal oleh pengawas Kemenag Kabupaten Batubara) dan evaluasi (meliputi tes lisan dan tertulis).

\section{DAFTAR PUSTAKA}

Abadi, Ghafiki Faroek. (2015). "Inovasi Pembelajaran Pendidikan Agama Islam Berbasis E-Learning" Tasyri': Jurnal Tarbiyah-Syariah Islamiyah, 22(2).

http://ejournal.kopertais4.or.id/pantur a/index.php/tasyri/article/view/1547.

Agustin, Farida, et.al. (2020). "Manajemen Pembelajaran Daring Menggunakan Education Smart Courses" Technomedia Journal, 5(1).

Ahmad, Sabaruddin.

(2021).

"Implementasi Supervisi Manajerial Pengawas dalam Meningkatkan Kinerja Guru PAI di MIN 4 Aceh Tenggara Era Covid-19" Mudabbir: Journal Research and Education Studies, 1(1). http://jurnal.permapendissumut.org/index.php/mudabbir/articl e/view/3.

Almasri, M Nazar. (2016). "Manajemen Sumber Daya Manusia: Implementasi dalam Pendidikan Islam" Kutubkhanah: Jurnal Penelitian Sosial Keagamaan, 19(2). http://ejournal.uinsuska.ac.id/index.php/Kutubkhanah/a rticle/view/2547.

Andiyanto, Tri. (2018). "Urgensi Supervisi Pendidikan dalam Meningkatkan Pengawasan Satuan Pendidikan" Jurnal Pendidikan Payan Mas, 2(1). http://ejournal.disdikbudlu.org/index. php/ejournal/article/view/28.

Andriana, Karmila. (2015). "Urgensi Perencanaan Pembelajaran Bahasa Arab dalam Pendidikan di Sekolah" Prosiding Konferensi Nasional
Bahasa Arab (Konasbara), 1. http://prosiding.arabum.com/index.php/konasbara/article/ view/22.

Ansori, M. Subhan, et.al. (2019). "Meningkatkan Pemahaman dan Keterampilan Ibadah Haji Bagi Peserta Didik, Guru, dan Wali Murid Melalui Pembelajaran Praktik Manasik Haji untuk Anak Usia Dini” JPPNu: Jurnal Pengabdian dan Pemberdayaan Nusantara, 1(1). http://journal.unublitar.ac.id/jppnu/in dex.php/jppnu/article/view/3.

Anwar, Khoirul. (2021). "Urgensi Evaluasi dalam Proses Pembelajaran" Rausyan Fikr: Jurnal Pemikiran \& Pencerahan, 17(1). http://jurnal.umt.ac.id/index.php/Rau syanFikr/article/view/4183.

Aryani, Rini \& Fitriani. (2020). "Inovasi Pembelajaran Pendidikan Kreatif" Prosiding Seminar Nasional PPS Universitas PGRI Palembang. https://jurnal.univpgri-

palembang.ac.id/index.php/Prosiding pps/article/view/3936.

Asmara, Yeni \& Dina Sri Nindianti. (2019). "Urgensi Manajemen Kelas untuk Mencapai Tujuan Pembelajaran" Sindang: Jurnal Pendidikan Sejarah dan Kajian Sejarah, 1(1). https://ojs.stkippgrilubuklinggau.ac.id/index.php/JS/artic le/view/192.

Assingkily, Muhammad Shaleh \& Mikyal Hardiyati. (2019). "Analisis Perkembangan Sosial-Emosional Tercapai dan Tidak Tercapai Siswa Usia Dasar" Al-Aulad: Journal of Islamic Primary Education, 2(2): 1931.

http://journal.uinsgd.ac.id/index.php/ al-aulad/article/view/5210.

Bararah, Isnawardatul. (2017). "Efektivitas Perencanaan Pembelajaran dalam Pembelajaran Pendidikan Agama Islam di Sekolah" Jurnal MUDARRISUNA: Media Kajian Pendidikan Agama Islam, 7(1). 
https://www.jurnal.ar-

raniry.ac.id/index.php/mudarrisuna/a rticle/view/1913.

Chotimah, Chusnul \& Muhammad Fathurrohman. (2018). Paradigma Baru Sistem Pembelajaran. Yogyakarta: Ar-Ruzz Media.

Creswell, John W. (2009). Research Design Qualitative, Quantitative, and Mixed Methods Approaches. California: SAGE Publications, Inc.

Dacholfany, M. Ihsan. (2015). "Reformasi Pendidikan Islam dalam Menghadapi Era Globalisasi" Akademika: Jurnal Pemikiran Islam, 20(1). https://ejournal.metrouniv.ac.id/index.php/ak ademika/article/view/441.

Darussalam. (2020). "Urgensi Pengawasan Sekolah dalam Meningkatkan Kinerja Guru Pendidikan Agama Islam di SMPN Serbajadi Aceh Timur" Al-Qiraah, 14(2). http://jurnal.kopertais5aceh.or.id/inde x.php/al-qiraah/article/view/124.

Djaelani, Moh. Solikodin. (2013). "Peran Pendidikan Agama Islam dalam Keluarga dan Masyarakat" Jurnal Ilmiah Widya, 1(2). https://ejournal.jurwidyakop3.com/index.php /jurnal-ilmiah/article/view/140.

Dolong, Jufri. (2016). "Teknik Analisis dalam Komponen Pembelajaran" Jurnal Inspiratif Pendidikan, 5(2). http://103.55.216.56/index.php/Inspir atif-Pendidikan/article/view/3484.

Fachri, Moh. (2018). "Urgensi Evaluasi Pembelajaran dalam Pendidikan" Edureligia, 2(1). https://doi.org/10.33650/edureligia.v $2 \mathrm{i} 1.758$.

Fitri, Anissa Nur, et.al. (2015). "Perlindungan Hak-Hak Anak dalam Upaya Peningkatan Kesejahteraan Anak" Prosiding Penelitian \& Pengabdian Kepada Masyarakat, 2(1).

http://journal.unpad.ac.id/prosiding/a rticle/view/13235.

Fitri, Annisa, et.al. (2017). "Perencanaan Pembelajaran Kurikulum 2013
Pendidikan Anak Usia Dini” Jurnal Ilmiah Potensia, 2(1). https://ejournal.unib.ac.id/index.php/ potensia/article/view/3032.

Fitriani, Rini. (2016). "Peranan Penyelenggara Perlindungan Anak dalam Melindungi dan Memenuhi Hak-Hak Anak" Jurnal Hukum Samudra Keadilan, 11(2). https://www.ejurnalunsam.id/index.p hp/jhsk/article/view/42.

Hasanah, Uswatun. (2018). "Metode Pengembangan Moral dan Disiplin Bagi Anak Usia Dini" Martabat: Jurnal Perempuan dan Anak, 2(1). http://ejournal.iaintulungagung.ac.id/index.php/martaba t/article/view/990.

Inawati, Asti. (2017). "Strategi Pengembangan Moral dan Nilai Agama untuk Anak Usia Dini" $A l$ Athfal: Jurnal Pendidikan Anak, 3(1).

http://202.0.92.5/tarbiyah/index.php/ alathfal/article/view/1422.

Ita, Efrida. (2018). "Manajemen Pembelajaran Pendidikan Anak Usia Dini di TK Rutosoro Kecamatan Golewa Kabupaten Ngada Flores Nusa Tenggara Timur" Jurnal Dimensi Pendidikan dan Pembelajaran, 6(1). http://journal.umpo.ac.id/index.php/d imensi/article/view/889.

Khaironi, Mulianah. (2017). "Pendidikan Moral pada Anak Usia Dini" Jurnal Golden Age, 1(1). https://ejournal.hamzanwadi.ac.id/index.php/ jga/article/view/479.

Khairuddin. (2020). "Implementasi Inovasi Manajemen Pembelajaran dalam Peningkatan Kualitas Pendidikan Agama Islam di Madrasah Aliyah Negeri 2 Model Medan" Disertasi. Universitas Islam Negeri Sumatera Utara Medan. http://repository.uinsu.ac.id/9560/.

Kristiawan, Muhammad \& Nur Rahmat. (2018). "Peningkatan Profesionalisme Guru Melalui 
Inovasi Pembelajaran" Jurnal Iqra': Kajian Ilmu Pendidikan, 3(2). https://journal.iaimnumetrolampung. ac.id/index.php/ji/article/view/348.

Lilian, Vin, et.al. (2014). "Inovasi Manajemen Pembelajaran Sejarah (Studi Deskriptif Kualitatif di SMA Negeri 1 Ujan Mas)" Tesis. Universitas Bengkulu. http://repository.unib.ac.id/8455/.

Lubis, Masruroh, et.al. (2020). "Pembelajaran Pendidikan Agama Islam Berbasis E-Learning (Studi Inovasi Pendidik MTs. PAI Medan di Tengah Wabah Covid-19)" Fitrah: Journal of Islamic Education, 1(1). http://jurnal.staisumateramedan.ac.id/index.php/fitrah/article/v iew/1.

Mafaliha, Mardiyana. (2020). "Upaya Guru dalam Mengembangkan Karakter Religius Anak Usia Dini di RA Raudlotunnahdliyah Dusun Ngrawan Desa Dolopo Kecamatan Dolopo Kabupaten Madiun" Skripsi. IAIN Ponorogo. http://etheses.iainponorogo.ac.id/114 $32 /$.

Mardhiah, et.al. (2020). "Inovasi Manajemen Pembelajaran Melalui Model Hypnoteaching dalam Meningkatkan Minat dan Kemampuan Membaca Al-Qur'an Bagi Anak Pemulung di Kota Makassar" Muslim Heritage: Jurnal Dialog Islam dengan Realitas, 5(2). https://doi.org/10.21154/muslimherit age.v5i2.2302.

Maujud, Fathul. (2018). "Implementasi Fungsi-fungsi Manajemen dalam Lembaga Pendidikan Islam (Studi Kasus Pengelolaan Madrasah Ibtidaiyah Islahul Muta'allim Pagutan)" Jurnal Penelitian Keislaman, $14(1)$. https://doi.org/10.20414/jpk.v14i1.49 0 .

Munawaroh, Hidayatu. (2017). "Pengembangan Model Pembelajaran dengan Permainan
Tradisional Engklek Sebagai Sarana Stimulasi Perkembangan Anak Usia Dini” Jurnal Obsesi: Jurnal Pendidikan Anak Usia Dini, 1(2). https://doi.org/10.31004/obsesi.v1i2. 19.

Nadlir, M. (2013). "Perencanaan Pembelajaran Berbasis Karakter" Jurnal Pendidikan Agama Islam, 1(2): $\quad 338-352$. https://doi.org/10.15642/jpai.2013.1. 2.338-352.

Nasrin. (2021). "Koordinasi Pengawas dan Kepala Madrasah dalam Meningkatkan Prestasi Kerja Guru MIN 8 Aceh Tenggara" Edu Society: Jurnal Pendidikan, Ilmu Sosial dan Pengabdian kepada Masyarakat, 1(1). http://jurnal.permapendissumut.org/index.php/edusociety/artic le/view/28.

Noor, Triana Rosalina. (2020). "Mengembangkan Jiwa Keagamaan Anak (Perspektif Pendidikan Islam dan Perkembangan Anak Usia Dini)" Kuttab: Jurnal Ilmu Pendidikan Islam, 4(2). http://journalfai.unisla.ac.id/index.ph p/kuttab/article/view/269.

Notosrijoedono, R.A. Anggraeni. (2015). "Menanamkan Kecerdasan Moral Sejak Anak Usia Dini pada Keluarga Muslim” Jurnal Tarbiyah, 22(1). http://jurnaltarbiyah.uinsu.ac.id/inde x.php/tarbiyah/article/view/9.

Nurdyansyah \& Eni Fariyatul Fahyuni. (2016). "Inovasi Model Pembelajaran Sesuai Kurikulum 2013" Nizamia Learning Center. http://eprints.umsida.ac.id/296/.

Nuriyah, Nunung. (2014). "Evaluasi Pembelajaran: Sebuah Kajian Teori" Edueksos: Jurnal Pendidikan Sosial dan Ekonomi, 3(1). https://www.syekhnurjati.ac.id/jurnal /index.php/edueksos/article/view/327

Nurlaila. (2018). "Urgensi Perencanaan Pembelajaran dalam Peningkatan Profesionalisme Guru" Sustainable: 
Jurnal Kajian Mutu Pendidikan, l(1).

http://jurnal.kopertais5aceh.or.id/inde x.php/al-qiraah/article/view/124.

Nurmalitasari, Femmi. (2015). "Perkembangan Sosial Emosi pada Anak Usia Prasekolah" Buletin Psikologi, https://journal.ugm.ac.id/buletinpsiko logi/article/view/10567.

Oviyanti, Fitri. (2013). "Tantangan Pengembangan Pendidikan Keguruan di Era Global" Nadwa: Jurnal Pendidikan Islam, 7(2). https://journal.walisongo.ac.id/index. $\mathrm{php} / \mathrm{Nadwa} /$ article/view/562.

Pamela, Maria Vani, et.al. (2015). "Persepsi Masyarakat Lokal dan Masyarakat Transmigrasi tentang Tanggung Jawab Orang Tua atas Pendidikan Anak" Jurnal Pendidikan dan Pembelajaran Khatulistiwa, 4(1).

https://jurnal.untan.ac.id/index.php/jp $\mathrm{dpb} /$ article/view/8884.

Pane, Aprida \& Muhammad Darwis Dasopang. (2017). "Belajar dan Pembelajaran" Fitrah: Jurnal Kajian Ilmu-ilmu Keislaman, 3(2). http://jurnal.iain-

padangsidimpuan.ac.id/index.php/f/a rticle/view/945.

Prabowo, Sugeng Listyo. (2010). "Perencanaan Pembelajaran pada Bidang Studi, Bidang Studi Tematik, Muatan Lokal, Kecakapan Hidup, Bimbingan dan Konseling" UIN Maliki Press. http://repository.uinmalang.ac.id/1616/.

Putriani, Pika. (2015). "Motivasi Orang Tua Menyekolahkan Anak di Pondok Pesantren Raudhatul Ulum" Skripsi. Universitas Muhammadiyah Palembang. http://repository.umpalembang.ac.id/id/eprint/211/.

Rahayu, Galih Dani Septiyan \& Dida Firmansyah. (2018). "Pengembangan Pembelajaran Inovatif Berbasis Pendampingan Bagi Guru Sekolah Dasar" Abdimas Siliwangi, 1(1). https://www.journal.ikipsiliwangi.ac. $\mathrm{id} /$ index.php/abdimas-

siliwangi/article/view/36.

Rahman, Abdul. (2018). "Urgensi Pedagogik dalam Pembelajaran dan Implikasinya dalam Pendidikan" Belajea: Jurnal Pendidikan Islam, 3(1).

http://repository.iaincurup.ac.id/50/.

Rohmah, Fitri Nur. (2017). "Urgensi Evaluasi untuk Pendidikan" Fikrotuna: Jurnal Pendidikan dan Manajemen Islam, 5(1). http://ejournal.kopertais4.or.id/madur a/index.php/fikrotuna/article/view/29 54.

Rosyad, Ali Miftakhu. (2019). “The Urgency of Learning Innovation on Islamic Religious Study" Al-Afkar: Journal of Islamic Studies, 2(1). https://al-

afkar.com/index.php/Afkar_Journal/a rticle/view/41.

Sada, Heru Juabdin. (2017). "Kebutuhan Dasar Manusia dalam Perspektif Pendidikan Islam" Al-Tadzkiyyah: Jurnal Pendidikan Islam, 8(2). https://doi.org/10.24042/atjpi.v8i2.21 26.

Saputro, Budiono. (2016). "Pengembangan Model Manajemen Pembelajaran Direct Instruction Berfokus Film dalam Pengantar Praktikum IPA" Holistik, $1(1)$. https://scholar.google.com/scholar?st art $=20 \& q=+$ inovasi+manajemen+pe mbelajaran\&hl=id\&as_sdt $=0,5$.

Sholikhah, Siti, et.al. (2019). "Motivasi Orang Tua Menyekolahkan Anak di KB Aisyiyah 30 Surabaya" Pedagogi: Jurnal Anak Usia Dini dan Pendidikan Anak Usia Dini, 5(2). http://journal.umsurabaya.ac.id/index.php/Pedagogi/ar ticle/view/3612.

Siregar, Lis Yulianti Syafrida. (2016). "Pendidikan Anak dalam Islam" Bunayya: Jurnal Pendidikan Anak, 1(2). https://www.jurnal.arraniry.ac.id/index.php/bunayya/articl 
e/download/2033/1505.

Sudrajat, Tedy. (2011). "Perlindungan Hukum Terhadap Hak Anak Sebagai Hak Asasi Manusia dalam Perspektif Sistem Hukum Keluarga di Indonesia" Kanun: Jurnal Ilmu Hukum, 13(2). http://erepository.unsyiah.ac.id/kanun/article /view/6245.

Sujatmoko, Emmanuel. (2010). "Hak Warga Negara dalam Memperoleh Pendidikan" Jurnal Konstitusi, 7(1). https://jurnalkonstitusi.mkri.id/index. php/jk/article/view/208.

Supriadi, Dudun. (2017). "Impelementasi Manajemen Inovasi dan Kreatifitas Guru dalam Meningkatkan Mutu Pembelajaran" IJEMAR: Indonesian Journal of Education Management \& Administration Review, 1(2). https://jurnal.unigal.ac.id/index.php/i jemar/article/view/944.

Suryapermana, Nana. (2017). "Manajemen Perencanaan Pembelajaran" Tarbawi: Jurnal Keilmuan Manajemen Pendidikan, 3(2). http://dx.doi.org/10.32678/tarbawi.v3 i02.1788.

Tatu, Hasna R. (2019). "Pengendalian Pendidikan Terhadap Media Pembelajaran dalam Urgensi Pembelajaran Daring pada Masa Pandemi Covid-19" Jurnal AlHimayah, $3(2)$. http://journal.iaingorontalo.ac.id/inde x.php/ah/article/view/2121.

Taubah, Mufatihatut. (2015). "Pendidikan Anak dalam Keluarga Perspektif Islam" Jurnal Pendidikan Agama Islam, $\quad 3(1)$. http://jurnalpai.uinsby.ac.id/index.ph p/jurnalpai/article/view/41.
Trenggonowati, Dyah Lintang \& Kulsum. (2018). "Analisis Faktor Optimalisasi Golden Age Anak Usia Dini Studi Kasus di Kota Cilegon" Journal Industrial Servicess, 4(1). https://jurnal.untirta.ac.id/index.php/j iss/article/view/4088.

Ulfiyah, Faiz Nadhifatu. (2017). "Peran Guru dalam Mendidik Perilaku Ibadah Anak Usia Dini di RA AlHidayah Gombang Pakel Tulungagung" Skrispi. IAIN Tulungagung. $\quad$ http://repo.iaintulungagung.ac.id/5552/.

Usman, A. Samad. (2017). "Tanggung Jawab Orang Tua Terhadap Pendidikan Anak dalam Perspektif Islam” Bunayya: Jurnal Pendidikan Anak, 2(1). http://103.107.187.25/index.php/bun ayya/article/viewFile/1324/984.

Vitasari, Hamidah Nur. (2017). "Motivasi Orang Tua Menyekolahkan Anak di Sekolah Berbasis Islam (Studi Kasus di Desa Singosari Mojosongo Boyolali)" Skripsi. IAIN Salatiga. http://erepository.perpus.iainsalatiga.ac.id/1 954/.

Widyanto, I Putu, et.al. (2020). "Implementasi Manajemen Pembelajaran Era Revolusi Industri 4.0 di Institut Agama Hindu Negeri Tampung Penyang Palangka Raya" Jurnal Smart, 6(1). https://blasemarang.kemenag.go.id/jo urnal/index.php/smart/article/view/98 1.

Yin, Robert K. (2009). Case Study Research: Design and Methods. California: SAGE Inc. 